\title{
Pengaruh lingkungan belajar dan kemandirian belajar terhadap hasil belajar mata pelajaran teknologi perkantoran
}

\author{
Az Zahra Nur Amalia Setyaningrum, Imam Bukhori* \\ Universitas Negeri Malang, Jl. Semarang No. 5 Malang, Jawa Timur, Indonesia \\ *Penulis korespondensi, Surel: imam.bukhori.fe@um.ac.id
}

Paper received: 2-1-2021; revised: 23-1-2021; accepted: 30-1-2021

\begin{abstract}
A good and comfortable learning environment can help students to concentrate and increase learning creativity. Learning independency is needed so that students may be responsible and capable to develop learning abilities by themselves. This research is a descriptive-correlational quantitative study which aims to obtain an overview of the variables studied and find whether there is an influence between each variable. This study applied three models of classical assumption test: (1) normality test; (2) heteroscedasticity test; (3) multicollinearity test. The data analysis techniques of this study were: (1) descriptive statistic analysis; (2) multiple linear regression analysis. The results showed that: (1) the learning environment of the students may be classified as good, the independence of the students was good, and most of the students had good learning outcomes; (2) there is a significant positive influence of the learning environment on the learning outcomes of the Office Technology;(3) there is a significant positive influence of learning independence on learning outcomes of the Office Technology; (4) there is a significant positive influence of the learning environment and learning independence on the learning outcomes of the Office Technology.
\end{abstract}

Keywords: learning environment, learning independences, learning outcomes

\begin{abstract}
Abstrak
Lingkungan belajar yang baik dan nyaman dapat memudahkan peserta didik untuk berkonsentrasi dan meningkatkan kreativitas belajar. Kemandirian belajar peserta didik diperlukan agar peserta didik mempunyai tanggung jawab dan mampu mengembangkan kemampuan belajar atas kemauan sendiri.Penelitian ini merupakan penelitian kuantitatif deskriptif-korelasional yaitu penelitian dengan tujuan untuk memperoleh gambaran tentang variabel yang diteliti dan menemukan ada tidaknya pengaruh antara masing - masing variabel. Dalam penelitian ini menggunakan tiga model uji asumsi klasik, yaitu: (1) uji normalitas;(2) uji heteroskedastisitas;(3) uji multikolinieritas. Teknik analisis data yang digunakan dalam penelitian ini yaitu: (1) analisis statistik deskriptif; (2) analisis regresi linier berganda. Hasil penelitian menunjukkan bahwa: (1) lingkungan belajar pada peserta didik dapat diklasifikasikan baik, kemandirian peserta didik baik, dan sebagian besar peserta didik memiliki hasil belajar yang baik; (2) ada pengaruh positif yang signifikan antara lingkungan belajar terhadap hasil belajar; (3) ada pengaruh positif yang signifikan antara kemandirian belajar; (4) ada pengaruh positif yang signifikan antara lingkungan belajar dan kemandirian belajar terhadap hasil belajar.
\end{abstract}

Kata kunci: lingkungan belajar, kemandirian belajar, hasil belajar

\section{Pendahuluan}

Pendidikan tidak lepas dari kegiatan belajar. Belajar merupakan suatu proses perubahan yaitu perubahan tingkah laku sebagai hasil interaksi dengan lingkungan dalam memenuhi kebutuhan hidupnya. Perubahan - perubahan tersebut akan nyata dalam seluruh aspek tingkah laku. Menurut Slameto (2013:2) “Belajar adalah suatu proses usaha yang dilakukan seseorang untuk memperoleh suatu perubahan tingkah laku yang baru secara keseluruhan, sebagai hasil pengalamannya sendiri dan interaksi dengan lingkungannya". Pendidikan sekarang ini berpijak pada keaktifan dan keefektifan proses belajar mengajar, apabila dalam

This work is licensed under a Creative Commons Attribution-ShareAlike 4.0 International License. 
hal tersebut dilaksanakan dengan baik maka kesuksesan pendidikan akan tercapai dan terlaksana.

Dalam proses pembelajaran, lingkungan merupakan sumber belajar yang berpengaruh dalam proses belajar dan perkembangan anak. Lingkungan belajar tidak hanya di dalam lingkungan sekolah, tetapi ada juga lingkungan belajar di dalam keluarga dan lingkungan belajar di dalam masyarakat.

Keberhasilan dalam pencapaian tujuan pembelajaran tidak lepas dari struktur kurikulum dan mata pelajaran yang diberikan. Teknologi Perkantoran merupakan salah satu mata pelajaran kelas X Kompetensi Keahlian Otomatisasi Tata Kelola Perkantoran yang terdapat pada struktur Kurikulum 2013 revisi. Mata pelajaran Teknologi Perkantoran bertujuan untuk membekali peserta didik agar dapat menguasai berbagai kegiatan perkantoran dalam menangani informasi, mulai dari input hingga distribusi dengan menggunakan sistem otomatis yaitu komputer. Penguasaan dalam teknologi perkantoran sangat diperlukan oleh peserta didik dalam menghadapi kegiatan praktik industri dan persiapan memasuki dunia kerja.

Tolak ukur keberhasilan peserta didik mempelajari teknologi perkantoran yaitu dapat dilihat dari prestasi belajarnya. Prestasi belajar teknologi perkantoran adalah hasil yang dicapai oleh peserta didik setelah mempelajari mata pelajaran teknologi perkantoran dan dinyatakan dalam bentuk nilai atau angka. Hasil belajar peserta didik dapat diketahui dengan melihat nilai ulangan harian, nilai harian, nilai tugas, nilai ujian tengah semester, nilai ujian akhir semester maupun nilai ujian nasional.

Pencapaian keberhasilan dalam belajar dipengaruhi oleh banyak faktor. Salah satunya yaitu lingkungan belajar, peran lingkungan yang baik akan mendorong hasil belajar dan meningkatkan kreativitas peserta didik. Menurut Hamalik (2013:195) "Lingkungan adalah sesuatu yang ada di alam sekitar yang memiliki makna dan/atau pengaruh tertentu terhadap individu". Menurut Baharuddin (2012:68) "Lingkungan merupakan sesuatu yang mengelilingi individu didalam hidupnya, baik dalam bentuk lingkungan fisik seperti orangtua, rumah, kawan bermain, dan masyarakat sekitar, maupun dalam bentuk lingkungan psikologi seperti perasaan - perasaan yang dialami, cita - cita, persoalan - persoalan yang dihadapi dan sebagainya". Lingkungan tidak dapat dipisahkan dalam kehidupan manusia, karena lingkungan selalu mengelilingi manusia. Antara manusia dengan lingkungan terdapat hubungan timbal balik, dimana manusia mempengaruhi lingkungan dan lingkungan mempengaruhi manusia.

Dalam proses pembelajaran, lingkungan merupakan sumber belajar yang berpengaruh dalam proses belajar dan perkembangan anak. Lingkungan belajar tidak hanya di dalam lingkungan sekolah, tetapi ada juga lingkungan belajar di dalam keluarga dan lingkungan belajar di dalam masyarakat. Menurut Slameto (2013:60) "Lingkungan belajar merupakan faktor eksternal yang berpengaruh terhadap hasil belajar yang terdiri dari lingkungan keluarga, lingkungan sekolah, dan lingkungan masyarakat". Kondisi lingkungan belajar yang baik seperti tersedianya fasilitas belajar, tempat belajar yang nyaman, suasana yang tenang, hubungan harmonis dengan lingkungan sekitar dapat memberikan dorongan kepada peserta didik sehingga hasil belajar peserta didik meningkat. Sebaliknya apabila kondisi lingkungan belajar kurang baik akan menurunkan semangat belajar peserta didik sehingga hasil belajar peserta didik akan menurun. 
Selain dari faktor lingkungan belajar ada juga faktor yang mempengaruhi hasil belajar peserta didik yaitu kemandirian belajar. Kemandirian belajar peserta didik diperlukan agar peserta didik mempunyai tanggung jawab dalam mengatur dan mendisiplinkan dirinya, serta mengembangkan kemampuan belajar atas kemauan sendiri. Kemandirian belajar perlu dimiliki oleh setiap peserta didik karena hal tersebut merupakan ciri dari kedewasaan orang terpelajar. Peserta didik dikatakan mandiri apabila mampu melakukan tugas belajar tanpa ketergantungan orang lain, mampu mengatasi masalah sendiri, mempunyai rasa percaya diri dan bertanggung jawab. Kemandirian belajar tidak terlepas dari kegiatan - kegiatan yang dapat meningkatkan hasil belajar. Jika kemandirian belajar tinggi maka hasil belajar akan meningkat begitu juga sebaliknya. Kemandirian belajar yang rendah mengakibatkan hasil belajar menurun. Ciri - ciri peserta didik mandiri dapat dilihat dari kemandirian belajar yang dimiliki oleh peserta didik, hal ini dikemukakan oleh Sumardiono (dalam Pratiwi \& Widayanti, 2012:142), antara lain yaitu dorongan internal, berorientasi tujuan, terampil mencari bahan, dan pandai mengelola diri.

\section{Metode}

Dalam penelitian ini kondisi yang sebenarnya digambarkan secara apa adanya, sehingga jenis penelitian ini bersifat deskriptif - korelasional. Metode deskriptif digunakan untuk menafsirkan dan memaparkan data variabel lingkungan belajar dan kemandirian belajar. Sedangkan dimaksud dalam korelasional karena penelitian ini bertujuan untuk mengetahui ada tidaknya pengaruh antara variabel - variabel bebas terhadap variabel terikat seperti dugaan teoritis. Dengan demikian, dalam penelitian deskriptif - korelasional bertujuan untuk mendeskripsikan pengaruh variabel lingkungan belajar dan kemandirian belajar peserta didik terhadap variabel hasil belajar peserta didik mata pelajaran teknologi perkantoran di SMK Muhammadiyah 5 dan SMK Cendika Bangsa Kepanjen

Berdasarkan penjelasan diatas, yang menjadi variabel bebas adalah lingkungan belajar $\left(X_{1}\right)$ dan kemandirian belajar $\left(X_{1}\right)$ dan variabel terikat yaitu hasil belajar peserta didik (Y).

Hubungan antar variabel dapat digambarkan sebagai berikut:

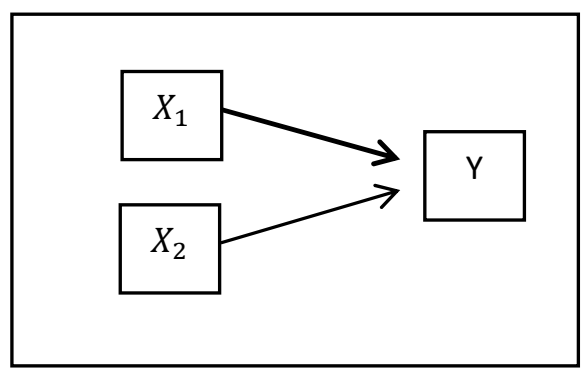

Gambar 1. Rancangan Penelitian

\section{Keterangan:}

$X_{1} \quad$ : Lingkungan Belajar (Variabel Ind ependen)

$X_{2} \quad:$ Kemandirian Belajar (Variabel Independen)

Y : Hasil Belajar (Variabel Dependen)

$\longrightarrow \quad$ : Garis pengaruh variabel X terhadap variabel Y secara Parsial 


\section{Hasil dan Pembahasan}

\subsection{Asumsi Normalitas}

Uji asumsi normalitas digunakan untuk menguji nilai residual yang dihasilkan dari regresi terdistribusi secara normal atau tidak. Model regresi yang baik adalah yang memiliki nilai residual yang terdistribusi dengan normal. Untuk mendeteksi apakah residual terdistribusi normal atau tidak, dapat dilihat melalui Normal P-P Plot. Residual dinyatakan normal apabila titik - titik residual berada di sekitar garis diagonal.

Berikut ini adalah hasil pengujian asumsi normalitas melalui Normal P-P Plot of regression standardized residual.

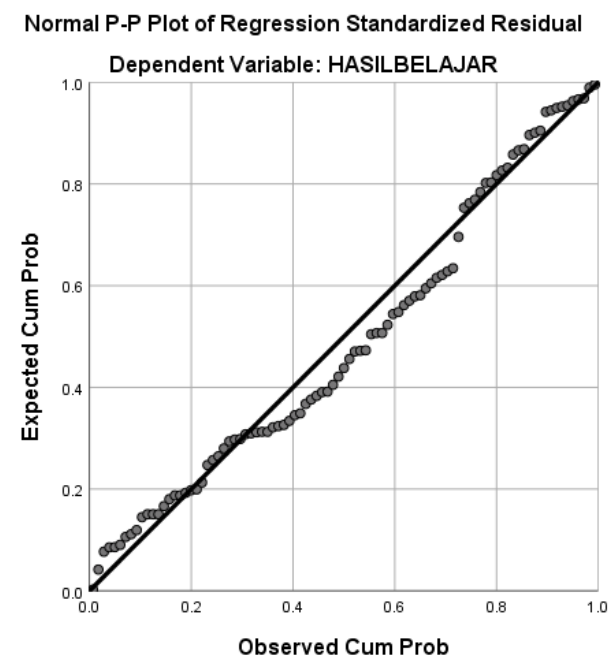

Gambar 41 Grafik P-P Plot of regression standardized residual

Berdasarkan grafik Normal P-P Plot diatas, titik - titik residual berada di sekitar garis diagonal. Dengan demikian dapat disimpulkan bahwa residual berdistribusi normal sehingga asumsi normalitas dinyatakan terpenuhi.

\subsection{Asumsi Heteroskedastisitas}

Uji heteroskedastisitas digunakan untuk mengetahui apakah dalam sebuah model regresi terjadi ketidaksamaan varian dari residual pada satu pengamatan ke pengamatan yang lain. Suatu regresi dinyatakan memiliki heteroskedastisitas apabila grafik Scatterplot terdapat titik - titik yang membentuk suatu pola tertentu yang teratur (bergelombang, melebar kemudian menyempit). 


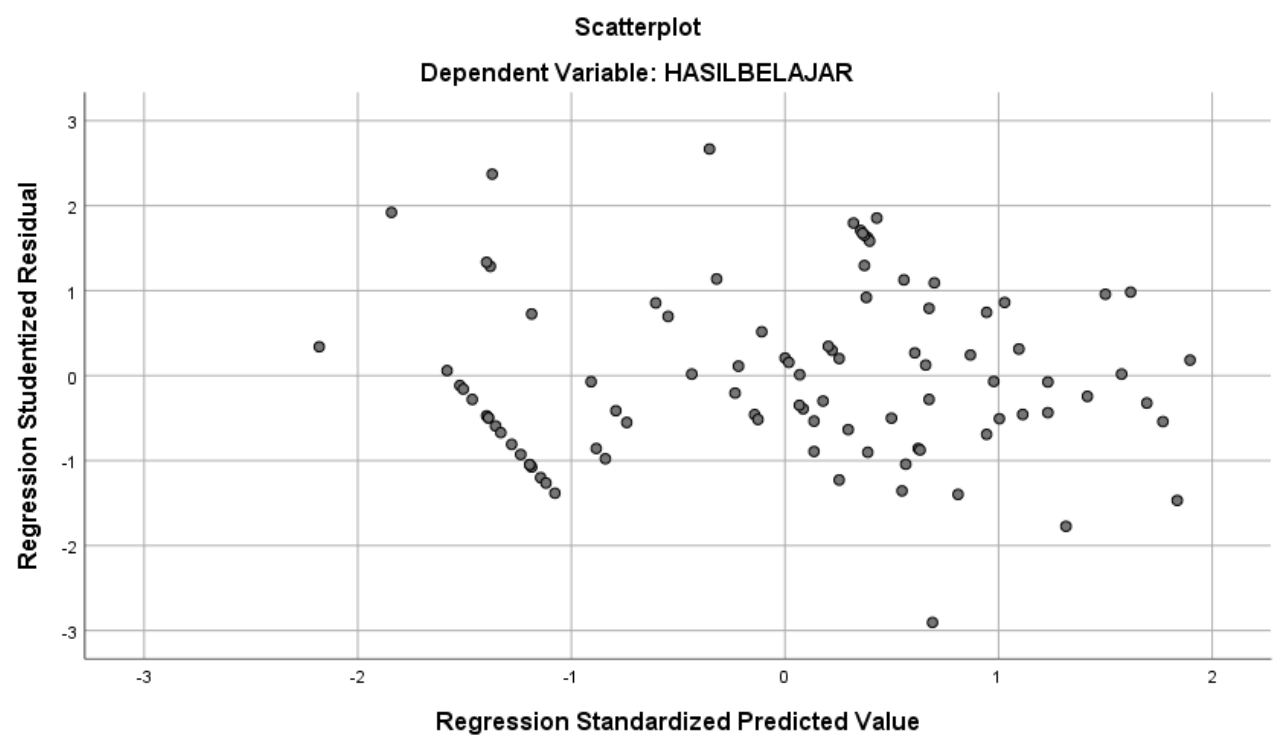

Gambar 42 Grafik Scatterplot

Berdasarkan scatter plot diatas, titik - titik residual menyebar secara acak. Dengan demikian dapat disimpulkan bahwa residual memiliki ragam yang homogen. Sehingga asumsi heteroskedastisitas dinyatakan terpenuhi.

\subsection{Asumsi Multikolinieritas}

Uji multikolinearitas bertujuan digunakan untuk mengetahui apakah terdapat korelasi hubungan antar variabel bebas (independen). Untuk mendeteksi masalah multikolinearitas dilakukan dengan melihat besarnya nilai VIF (Variance Inflation Factor). Jika nilai Tolerance $\leq$ $0,10 \mathrm{VIF}$ atau sama dengan nilai VIF $\geq 10$ maka model regresi tersebut dapat dikatakan terjadi multikolinieritas.

Tabel 41 Hasil Uji Multikolinearitas

\begin{tabular}{ccc}
\hline \multirow{2}{*}{ Model } & \multicolumn{2}{c}{ Collinierity Statistics } \\
\cline { 2 - 3 } & Tolerance & VIF \\
\hline 1 (constant) & & \\
\hline Lingkungan Belajar & 0,241 & 4,149 \\
\hline Kepercayaan Diri & 0,241 & 4,149 \\
\hline
\end{tabular}

Hasil uji multikolinearitas pada Tabel 4.4 menunjukkan bahwa nilai VIF untuk variabel lingkungan belajar dan kemandirian belajar 4,149 bisa dikatakan $\leq 10$ dan nilai tolerance sebesar 0,241 bisa dikatakan $\geq 0,10$ maka dapat disimpulkan bahwa dalam penelitian ini tidak terjadi gejala multikolinieritas. Sehingga dapat disimpulkan bahwa asumsi multikolonieritas dinyatakan terpenuhi.

\subsection{Analisis Regresi Linier Berganda}

Penelitian ini terdiri dari dua variabel, yaitu variabel bebas (X) dan variabel terikat $(\mathrm{Y})$. variabel bebas dalam penelitian ini adalah lingkungan belajar $\left(X_{1}\right)$ dan kemandirian belajar 
$\left(X_{2}\right)$, selanjutnya variabel terikat dalam penelitian ini adalah hasil belajar (Y). Langkah yang dilakukan setelah analisis statistik deskriptif yaitu menganalisis dengan regresi linier berganda, yaitu dideskripsikan sebagai berikut.

Tabel 42 Hasil Uji Regresi Linier Berganda Coefficientsa

\begin{tabular}{|c|c|c|c|c|c|c|c|}
\hline \multirow{2}{*}{\multicolumn{2}{|c|}{ Model }} & \multicolumn{2}{|c|}{$\begin{array}{l}\text { Unstandardized } \\
\text { Coefficients }\end{array}$} & \multirow{2}{*}{$\begin{array}{l}\text { Standardized } \\
\text { Coefficients } \\
\text { Beta }\end{array}$} & \multirow[b]{2}{*}{$\mathrm{t}$} & \multirow[b]{2}{*}{ Sig. } & \multirow[b]{2}{*}{ Ket } \\
\hline & & $\mathrm{B}$ & Std. Error & & & & \\
\hline 1 & (Constant) & 5.134 & 2.933 & & 1.751 & .083 & \\
\hline & $\begin{array}{l}\text { Lingkungan belajar } \\
\text { (X1) }\end{array}$ & .602 & .062 & .685 & 9.644 & .000 & Diterima \\
\hline & $\begin{array}{l}\text { Kemandirian belajar } \\
\text { (X2) }\end{array}$ & .336 & .084 & .285 & 4.006 & .000 & Diterima \\
\hline
\end{tabular}

a Dependent Variable: Hasil belajar

Berdasarkan analisis data dengan menggunakan program IBM SPSS 26 for windows, maka diperoleh hasil persamaan regresi sebagai berikut:

$$
\mathrm{Y}=5,134+0,602 X_{1}+0,336 X_{2}+\mathrm{e}
$$

Terdapat hasil dari perhitungan menggunakan program IBM SPSS 26 for windows, nilai dari lingkungan belajar $\left(X_{1}\right)$ terhadap hasil belajar $(Y)$ sebesar 0,602 dan nilai kemandirian belajar $\left(X_{2}\right)$ terhadap hasil belajar $(Y)$ sebesar 0,336. Persamaan regresi tersebut dapat diartikan dengan adanya peningkatan lingkungan belajar peserta didik sebesar satu satuan maka hasil belajar peserta didik meningkat 0,602 dengan asumsi variabel lain bernilai tetap dan kenaikan kemandirian belajar peserta didik sebesar satu satuan maka hasil belajar peserta didik akan meningkat sebesar 0,336 dengan asumsi variabel lain bernilai tetap. Sedangkan konstanta sebesar 5,134 artinya jika lingkungan belajar $\left(X_{1}\right)$ dan kemandirian belajar $\left(X_{2}\right)$ nilainya 0, maka hasil belajar (Y) nilainya adalah 5,134. Selain itu diketahui pula koefisien determinasi (Adjusted R Square) sebesar 0,888. Ini berarti 80\% perubahan variabel hasil belajar disebabkan oleh lingkungan belajar dan kemandirian belajar. Sedangkan sisanya $20 \%$ disebabkan oleh faktor - faktor lain, seperti kepercayaan diri, motivasi, bakat dan disiplin belajar, dan motivasi belajar.

\subsection{Hasil Uji Hipotesis}

Uji t dalam penelitian ini digunakan untuk menguji ada tidaknya variabel bebas lingkungan belajar $\left(X_{1}\right)$ dan kemandirian belajar $\left(X_{2}\right)$ secara parsial terhadap variabel terikat hasil belajar peserta didik (Y). pengujian dilakukan dengan membandingkan nilai signifikan hasil uji t dengan taraf signifikan $\alpha$ sebesar 0,05 (5\%). Jika nilai signifikansi > 0,05 maka Ha ditolak (tidak signifikan) jika nilai signifikansi $<0,05$ maka Ha diterima (signifikan), atau dengan membandingkan $t_{\text {hitung }}$ dengan $t_{\text {tabel }}$ jika $t_{\text {hitung }}<t_{\text {tabel }}$ maka Ho diterima dan Ha ditolak, apabila jika $t_{\text {hitung }} \geq t_{\text {tabel }}$ maka Ho ditolak dan Ha diterima. Hasil perhitungan uji $\mathrm{t}$ dapat dilihat pada tabel 4.5

Pengujian hipotesis secara parsial pengaruh masing - masing variabel bebas terhadap variabel terikat adalah sebagai berikut. 


\subsubsection{Pengaruh Lingkungan Belajar $\left(X_{1}\right)$ terhadap Hasil Belajar $(Y)$}

Dari hasil analisis regresi linier berganda diketahui nilai $t_{\text {hitung }}=9,644$ dengan $t_{\text {tabel }}$ 1,986 dan signifikansi yang diperoleh sebesar 0,000 dengan taraf signifikansi 5\% $(0,05)$. Hal ini menunjukkan bahwa $t_{\text {hitung }} 9,644 \geq t_{\text {tabel }} 1,986$. Sedangkan signifikansi $0,000>$ alpha $(\alpha)$ pada taraf signifikansi 5\% (0,05). Maka dapat disimpulkan bahwa Ha diterima dan Ho ditolak yang berarti "lingkungan belajar berpengaruh positif dan signifikan terhadap hasil belajar mata pelajaran teknologi perkantoran kelas X Otomatisasi Tata Kelola Perkantoran SMK Muhammadiyah 5 Kepanjen dan SMK Cendika Bangsa Kepanjen”.

\subsubsection{Pengaruh Kemandirian Belajar $\left(X_{2}\right)$ terhadap Hasil Belajar $(Y)$}

Dari hasil analisis regresi linier berganda diketahui nilai $t_{\text {hitung }}=4,006$ dengan $t_{\text {tabel }}$ 1,986 dan signifikansi yang diperoleh sebesar 0,000 dengan taraf signifikansi 5\% (0,05). Hal ini menunjukkan bahwa $t_{\text {hitung }} 4,006>t_{\text {tabel }} 1,986$. Sedangkan signifikansi $0,000>$ alpha $(\alpha)$ pada taraf signifikansi 5\% $(0,05)$. Maka dapat disimpulkan bahwa Ha diterima dan Ho ditolak yang berarti " Kemandirian belajar berpengaruh terhadap hasil belajar mata pelajaran teknologi perkantoran kelas X Otomatisasi Tata Kelola Perkantoran SMK Muhammadiyah 5 Kepanjen dan SMK Cendika Bangsa Kepanjen”.

Berdasarkan analisis regresi linier berganda dengan dua variabel bebas digunakan Adjusted $R$ Square sebagai koefisien determinasi. Nilai koefisien determinasi digunakan untuk melihat besarnya pengaruh lingkungan belajar dan kemandirian belajar terhadap hasil belajar peserta didik. Berdasarkan perhitungan dengan bantuan program IBM SPSS 26 for windows diperoleh nilai koefisien determinasi secara simultan Adjust $R$ Square sebesar 0,888, jadi dapat disimpulkan bahwa persentase pengaruh secara simultan variabel bebas lingkungan belajar dan kemandirian belajar terhadap variabel terikat hasil belajar sebesar 88,8\%. Sedangkan sisanya sebesar $100 \%-88,8 \%=11,2 \%$ dipengaruhi oleh variabel lain yang tidak termasuk dalam variabel penelitian.

\section{Simpulan}

Berdasarkan penelitian yang telah dilakukan tentang pengaruh lingkungan belajar dan kemandirian belajar terhadap hasil belajar peserta didik kelas X pada mata pelajaran Teknologi Perkantoran di SMK Muhammadiyah 5 Kepanjen dan SMK Cendika Bangsa Kepanjen. Dari hasil penelitian yang telah dijabarkan pada Bab V, maka dapat diambil kesimpulan sebagai berikut: (1) Peserta didik kelas X di SMK Muhammadiyah 5 Kepanjen dan SMK Cendika Bangsa Kepanjen memiliki lingkungan belajar yang baik, memiliki kemandirian belajar yang baik, dan memiliki rata - rata hasil belajar mata pelajaran Teknologi Perkantoran yang cukup baik. (2) Dari hasil penelitian yang telah dilakukan terdapat pengaruh positif yang signifikan antara lingkungan belajar terhadap hasil belajar peserta didik kelas X pada mata pelajaran Teknologi Perkantoran di SMK Muhammadiyah 5 Kepanjen dan SMK Cendika Bangsa Kepanjen. (3) Dari hasil penelitian yang telah dilakukan terdapat pengaruh positif yang signifikan antara kemandirian belajar terhadap hasil belajar peserta didik kelas X pada mata pelajaran Teknologi Perkantoran di SMK Muhammadiyah 5 Kepanjen dan SMK Cendika Bangsa Kepanjen. (4) Dari hasil penelitian yang dilakukan terdapat pengaruh positif yang signifikan antara lingkungan belajar dan kemandirian belajar terhadap hasil belajar peserta didik kelas X pada mata pelajaran Teknologi Perkantoran di SMK Muhammadiyah 5 Kepanjen dan SMK Cendika Bangsa Kepanjen. 


\section{Daftar Rujukan}

Smp, P. D. D. S. M. P. Arikunto, S.(2013). Prosedur Penelitian, suatu pendekatan praktik. Jakarta: Rineka Cipta. Sugiyono.(2014). Statistika Untuk Penelitian. Bandung: Alfabeta. Sugiyono.(2011). Metode Penelitian Kombinasi (Mixed Methods). Bandung: Alfabeta. Jurnal Ppkn. Unj Online, 1(2), 2337-5205.Baharuddin. (2012). Psikologi Pendidikan. Yogyakarta: Ar-Ruzz Media.

Cooper, D. R., \& Emory, W. (1995). Business Research Methods. (Terjemahan: Ellen Gunawan dan Imam Nurmawan), Homewood, IL: Richard D. Irwin.

Dimyati, M. (2013). Belajar \& Pembelajaran. Jakarta: Rineka Cipta.

Djamarah, S. B., \& Zain, A. (2010). Strategi Belajar Mengajar, Rineka Cipta.

Dwisavitri. N. (2012). Pengaruh Perhatian Orang Tua dan Kemandirian Belajar terhadap Prestasi Belajar Mengelola Kartu Peredian Peserta didik Kelas XI Kompetensi Keahlian Akuntansi SMK YPKK 2 Sleman Tahun Ajaran 2011/2012. Jurnal Kajian Pendidikan \& Akuntansi Indonesia, 1(2).

Sanjaya, H. Ghozali, I. (2016). Aplikasi Analisis Multivariete dengan Program IBM SPSS 23 (VIII). Semarang: Badan Penerbit Universitas Diponegoro.

Guo, J., Yang, L., \& Shi, Q. (2017). Effects of perceptions of the learning environment and approaches to learning on Chinese undergraduates' learning. Studies in Educational Evaluation, 55, 125-134.

Hamalik, O. (2001). Proses belajar mengajar.

Hidayat, M. (2017). Pengaruh Kebiasaan Belajar, Lingkungan Belajar, dan Dukungan Orang Tua Terhadap Prestasi Belajar Mata Pelajaran Ekonomi Pada Siswa Kelas IX IPS di MAN Bangkalan. Jurnal Ekonomi Pendidikan dan Kewirausahaan, 3(1), 103-114.

Kriyantono, R., \& Sos, S. (2014). Teknik praktis riset komunikasi. Prenada Media.

Kuncoro, M. (2004). Metode Kuantitatif: Teory dan aplikasi untuk Bisnis dan Ekonomi. Ed 2.

Kurniasari, F. W. (2013). Pengaruh Lingkungan Belajar dan Motivasi Belajar Terhadap Prestasi Belajar IPS Siswa SMPN 3 Wonosobo. OIKONOMIA-Jurnal Pendidikan Ekonomi, 2(3).

Kurniawan, E. A. (2014). Pengaruh Kemandirian Belajar Dan Sikap Ilmiah Dalam Metode Eksperimen Berbasis Verifikasi Terhadap Hasil Belajar IPA Fisika Siswa Kelas VII Semester Genap SMP N 2 Wonosobo Tahun Pelajaran 2012/2013 (Doctoral dissertation, Pendidikan Fisika-FKIP).

Nurhayati, E. (2018). Psikologi pendidikan inovatif(Vol. 2). Pustaka Pelajar.

Aini, P. N., \& Taman, A. (2012). Pengaruh kemandirian belajar dan lingkungan belajar siswa terhadap prestasi belajar akuntansi siswa kelas xi ips sma negeri 1 sewon bantul tahun ajaran 2010/2011. Jurnal Pendidikan Akuntansi Indonesia, 10(1).

Pratiwi, I., \& Widayati, A. (2012). Pembelajaran Akuntansi Melalui Reciprocal Teaching Model Untuk Meningkatkan Penguasaan Konsep dan Kemandirian Belajar dalam Materi Mengelola Administrasi Surat Berharga Jangka Pendek Siswa Kelas X Akuntansi 1 SMK Negeri 7 Yogyakarta Tahun Pelajaran 2011/2. Jurnal Pendidikan Akuntansi Indonesia, 10(2).

Purwanto, N., \& Pd, M. (2011). Statistika Untuk Penelitian. Yogyakarta: Pustaka Pelajar.

Ranti, M. G., Budiarti, G., \& Trisna, B. N. (2017). Pengaruh Kemandirian Belajar (Self-Regulated Learning) Terhadap Hasil Belajar Mahapeserta didik pada Matakuliah Struktur Aljabar. Jurnal Pendidikan Matematika, 3(1): 75-83.

Saragih, D. K. (2017). Pengaruh Kemandirian, Gaya Belajar Dan Lingkungan Belajar Terhadap Hasil Belajar Akuntansi Siswa Kelas X Program Keahlian Akuntansi SMK PGRI 3 Sidoarjo. Jurnal Ekonomi Pendidikan Dan Kewirausahaan, 2(1), 29-41.

Slameto. (2013). Belajar dan Faktor-Faktor yang Mempengaruhinya. Jakarta: PT Rineka Cipta.

Sudikno, I. S. (2014). Pengaruh Lingkungan Keluarga, Lingkungan Sekolah, Disiplin Belajar dan Motivasi Belajar terhadap Prestasi Belajar Ekonomi Siswa SMA Kelas XI IPS SMA PGRI 1 Taman Pemalang. Economic Education Analysis Journal, 3(1).

Sudjana, N. (2013). Dasar - Dasar Proses Belajar Mengajar. Bandung: Sinar Baru.

Sudjana, N. (2014). Penilaian hasil proses belajar mengajar.

Sugiyono. (2015). Metode Penelitian Pendidikan Pendekatan Kuantitatif, Kualitatif, dan R\&D. Bandung: Alfabeta. 
Jurnal Ekonomi, Bisnis dan Pendidikan, 1(1), 2021, 15-23

Sukmadinata, N. S. (2011). Landasan Psikologi Proses Pendidikan. Bandung: Remaja Rosdakarya.

Suliyanto, S. E., \& Si, M. (2006). Metode Riset Bisnis. Yogyakarta: Andi.

Suprijono, A. (2012). Cooperative Learning Teori \& Aplikasi Paikem. Yogyakarta: Pustaka Belajar.

Suratno, S. (2014). Pengaruh Lingkungan Keluarga Dan Lingkungan Pergaulan Terhadap Prestasi Belajar Ekonomi Siswa. Dinamika Pendidikan, 9(1).

Syah, M. (2010). Psikologi Pendidikan, Bandung: PT. Remaja Rosdakarya.

Umar, H. (2016). Metode penelitian untuk skripsi dan tesis bisnis. PT. RajaGrafindo Persada.

Komputer, W. (2012). Solusi Praktis \& Mudah menguasai SPSS 20 Untuk Pengolahan Data. PenerbitWahana Komputer Semarang \& ANDY Yogyakarta.

Walgito, B. (2010). Bimbingan dan konseling (Studi dan Karir). Yogyakarta: CV Andi Offset.

Wulansari, L. (2016). Pengaruh Kemandirian Belajar dan Minat Terhadap Prestasi Belajar Pelajaran Ilmu Pengetahuan Sosial (Survei Pada Sekolah Menengah Pertama Swasta. Jurnal Faktor UNINDRA, 3(2), 141-156.

Yana, E., \& Nurjanah, N. (2014). Pengaruh Lingkungan Keluarga dan Lingkungan Sekolah Terhadap Prestasi Belajar Siswa Pada Mata Pelajaran Ekonomi di Kelas XI IPS SMA Negeri 1 Ciledug Kabupaten Cirebon. Edunomic Jurnal Pendidikan Ekonomi, 2(1). 